Article

\title{
Earth-Sheltered House: A Case Study of Dobraca Village House near Kragujevac, Serbia
}

\author{
Aleksandar Rudnik Milanović ${ }^{1, *}$, Nadja Kurtović Folić ${ }^{2}$ and Radomir Folić ${ }^{2}$ \\ 1 Rudnik Urbanism Design Architecture, 34000 Kragujevac, Serbia \\ 2 Departmant of architecture and urbanism, Faculty of Technical Sciences, University of Novi Sad, \\ 21000 Novi Sad, Serbia; nfolic@uns.ac.rs (N.K.F.); folic@uns.ac.rs (R.F.) \\ * Correspondence: office@rudnik.co.rs
}

Received: 14 August 2018; Accepted: 7 October 2018; Published: 11 October 2018

check for updates

\begin{abstract}
This paper presents the case study of the authors' design of the earth-sheltered house in Village Dobraca near Kragujevac, Serbia, in the context of development and some thermal properties of the underground housing. The historical insight, in brief, provides a better understanding of the reasons for their modern use as energy efficient and sustainable structures. It shows that underground houses even today are more thermally efficient than above ground houses since, besides earth, there is no need for new additional thermal layers. The article also includes a review of the representative physical forms of the underground housing through different periods, with the result of measurement of their main properties. The study of the underground housing structures provides an insight of the relation between the location and typology of underground homes in a contest of climate zones. These structures have an almost constant temperature, which provides the primary "comfort" condition in which the man is determined to live in. The results on property-based monitoring data showed that the earth-sheltered house could provide the thermal comfort that is close to the ideal human needs temperature. Today, the new materials and especially the solar, geothermal, and wind accessories, enables the maximum sustainability of these specific building structures and provides them with an even better energy efficiency.
\end{abstract}

Keywords: earth-sheltered house; underground housing; historical insight; property-based monitoring data; sustainability

\section{Introduction}

Underground residential architecture is neither a new a concept, nor is its use discontinued; it is noticed that today there is a large number of buildings belonging to a group of subterranean structures bearing different denominations. Traditionally, these structures were built, above all, in the cases where the level of energy consumption for their functioning is reduced to the minimum. Underground housing, began when natural holes and natural or artificial caves were used, or primitive artificial structures were created [1]. Modern underground architecture is particularly developed in the field of housing. One of the main purpose of using this typological form of housing, is the ability to save energy by using the earth as an insulator, as well as other passive systems, such as solar, geothermal or wind energy for generating all the clean energy needed for the functioning of the houses [2]. In theory and practice there are two main types of this specific architecture. The first type is underground earth-sheltered home, built below the level of terrain or completely underground. These types of underground structure provide enough functional needs for living space through the atrium as a central outdoor courtyard. The second type is bermed earth-sheltered homes, which could be built above the terrain, or partially buried in the grade, with earth covering one or more walls. In most cases, these structures have only one facade, with the earth that covers the other sides [3]. 
The main objective of this research is to determine correlations between the earth-sheltered house and the soil depth, and to improve their thermal efficiency with some additional energy renewable resources. A critically analysis of the underground main housing types is aimed in order to identify factors that contribute the house performance and their thermal efficiency. To date, the underground houses and their thermal efficiency have been mostly analysed through the relation between their structural and thermal characteristic, and less within the connection between the soil depth, location of the houses, and climate zones.

Rob Roy [4], as an advocate of the theory and practice of underground houses, starts his book with defining a profound typology of these structures, based on a very clear description that refers to two different approaches to subsurface dwelling: The bermed house and the chambered house. The bermed house involves construction of the structure at/or close to original grade and "berming" the side walls of the building with earth as well as covering the roof with earth and sod. In the chambered house, the entire structure is below the original grade. The characteristics of underground houses are often used to describe their position and the benefits that these structures have in regard to atmospheric conditions, but also their energy savings properties in their use. In addition to these very positive characteristics of the underground homes according to Ray G. Scott [5], once you are closed $1.2 \mathrm{~m}$ or $1.5 \mathrm{~m}$ underground, with every exterior exposure, you can expect to find year around temperature stabilizing. The construction of underground houses can be viewed in the context of the structural typological aspect similarity, but thermal characteristics of the earth sheltered houses according to the University of Minnesota studies [6], have resulted primarily from anticipation of substantial energy savings. In typical above ground structures, energy is wasted due to unwanted heating or cooling of the surroundings. Energy efficiency and thermal aspects of an underground structure can also be linked to the present day's criteria related to the ecological properties of buildings. The development of modern underground architecture has its similarities, with ecologically responsible design since the energy crisis of 1972 [7]. In this paper a global review of the evolutionary development of underground housing is made. The historical periods when this type was especially developed and used are considered also in the relation to their thermal efficiency. The development of underground residential physical structures intensified at the turn of this century, precisely with the emergence of innovations in the area of building technology, the emergence of new materials and energy supply systems. In this sense, underground structures can certainly be viewed through the aspect of long-term potential benefits of earth-covered buildings, which has to do with their substantial independence from temporary power outages [8]. In conclusion, it is recommended that wider use of underground housing could be favorable from the aspect of thermal characteristics.

\section{Historical Development Review of Underground Housing}

The chronological study of underground housing starts with the results of archaeological research of human origin. From the very beginning, people used various forms of shelter, including various forms of caves, holes, pits, or natural recesses cut in the rocks, which were a form of natural underground habitats. During the Neolithic period, people gradually abandoned the woodland, mountainous regions and settled in fertile plains. The mental effort that enabled people to start building, and not to use natural shelters, is a segment of the so-called "Neolithic revolution". In Iran, one of the cradles of civilization, there are still well-preserved remains of a whole series of underground dwellings. In the area of Maymand, the winter troglodyte houses were carved out of the soft rock, in layers of up to five houses/apartments in height. The remains of the settlement today consist of 400 identified houses and 123 units, which are authentic and intact. This settlement represents one of Iran's oldest surviving villages. It has been continuously inhabited for 2000 or 3000 years, and some archaeologists claim that the village belongs even to the Mesolithic period [9]. The Orkney, the so called "Neolithic Heart", which was declared a UNESCO World Heritage Site in 1999, includes a group of Neolithic Monuments to the Scottish Archaeology Archipelago and consists of a large tombstone with Maas Hove, two ceremonies of stone circles (Stenness and Brodgar Ring) and settlements. Skara 
Brae is a Neolithic settlement with earth sheltered residential buildings built between 3180 and 2500 B.C. The appearance of underground residential architecture can be perceived on all continents. In addition to the physical structures that were built by human hands, still were natural shelters, which were later converted to housing. Mesa Verde National Park in Colorado is the most valuable preserved habitat that represent the apex of architectural sophistication of the Northern San Juan Ancestral Puebloan culture (550 to 1300 A.D.). There are various sizes of structure on the site that were built from sandstone and mud mortar. In the case of Mesa Verde, there is a rare situation of two various underground structures on the site. The first observation is that the whole village was built under the cliff, and the second is that besides masonry-walled villages there is also a pit house settlement on the site [10]. Besides the Mesa Verde, the site of S. Eustachius in Göreme, Cappadocia, Turkey, represents the very unique fragment of the rupestrian culture heritage. These structures were built as subterranean shelters. Located in a zone of volcanic origin, the settlements were made thanks to the natural plasticity of the environment, that enabled the ancient inhabitants to build the space for a living and in the same time as the shelters that could save their lives from the enemy attack. In periods of intensive warfare and destruction, people used the underground structures as living forms of protection from an enemy. The structures carved in vertical slopes of loess like corridors and used for housing, and, the name of the" lagum" is still used in the Vojvodina region, Serbia. Maintaining constant temperature conditions in residential buildings in the 21st century is becoming one of the major aspects that significantly affects the quality of life. The deeper from the surface of the earth the more stable the temperature of the earth. Studies indicate that the relative temperature fluctuation is stabilized at the depth of $0.2 \mathrm{~m}$, while at two $\mathrm{m}$ below the surface of the earth the temperature is equal to the average annual temperature [11]. Asia and Africa are certainly continents where the natural environment is used today for these purposes.

The new underground residential architecture arises with increased awareness for energy consumption and rests on the experience of anonymous builders of underground facilities, whose concepts today are innovative solutions for the housing problem of the 21st century man.

\section{Methodological Approach}

This paper presents a Case study based on the analysis of the underground housing from different periods and from different locations, with an emphasis on the thermal characteristics that affect the energy efficiency and comfort of life. The analysis was conducted through different historical periods to highlight the advantages and disadvantages of this type of housing. Based on various ways of building underground houses in relation to the terrain, the division into underground buildings integrated into the terrain (buried in rocks and buried in the fields), and true underground buildings built in the ground and bermed earth-sheltered buildings was accepted. Dobraca house near Kragujevac has been shown in a way that very old historical examples can serve as good inspiration for experimental thermal efficient design in 21st century. The method analysis of thermal characteristics, based on external and internal temperature measurements and wind speed in a certain period of time is shown. As a basis for the conclusion and recommendations, a review of the quoted references concerning research at different locations as well as the work of the author is used.

\section{The Basic Types of Underground Houses}

\subsection{Underground Buildings Integrated into the Existing Ambient}

The Chinese model of underground residential architecture (in addition to the Yaodong of the atrium type construction), as the most prominent model, has elevation type facilities created by the integration of the premises into the terrain. There are two types of underground structures; facilities that were buried in the rocks and those that were buried in the field, serving as the inner yard, called yaodong wells or flooded yards. The Loess Plateau, covering $400,000 \mathrm{~km}^{2}$, spreads over the whole of the Shanxi province and great areas of Shaanxi, Ningxia, Gansu, and Henan provinces. The Loess 
Plateau, with cave dwellings cut into the friable loess, was inhabited in ancient times [12]. The "troglodytes" still live in the types of housing units that can be found as a group of desert villages in North Africa, such as Matmata in the Bula region of Tunisia. "Troglodytes" housing is made by hollowing the core shafts in the ground and then from those holes, used as small courtyards, the houses interiors were cut in the dry vertical earthen "walls". This type of underground living is characteristic for its constant temperature that allows adequate functioning of these units, even during the winter period.

\subsection{True Underground Buildings}

One of the rare examples of completely underground facilities is the mining area and the town of Coober Pedy in South Australia. Coober Pady is an underground city in South Australia, located $850 \mathrm{~km}$ North of Adelaide. Over a long period of time, isolated and remote, it was experiencing cold nights in winter and heat in summer period. Such conditions forced their inhabitants to live in the caves excavated on the slopes of the hills next to the city. Due to the natural insulation provided by the ground, underground structures are thermally efficient [13]. The temperature varies between $35^{\circ} \mathrm{C}$ and $45^{\circ} \mathrm{C}$ in the shade, and in the summer period, more than half of the population of 4000 people lives below, where temperatures remain constant and pleasant. Coober Pedy opal fields were discovered in 1913 and cover an area of $4.954 \mathrm{~km}^{2}$. The similar type of structure could be found in Kandovan village in the district of Sahand in the central region of the province of Osku East Azerbaijan in Iran. In this unique village, homes are not only built on mountains, but carved into it. This rocky structure, which is compressed and shaped into pile pillars containing pockets ideal for housing, originates from volcanic ash and debris arising from the eruption of Sahand Mountain.

\subsection{Bermed Earth Sheltered Buildings of an Elevation Type}

For the purpose of promoting energy-efficient, socially and spatially acceptable construction structures, the Greater Norfolk City of Great Britain has for the first time approved the construction of underground residential architecture as a grant-based construction, with the explanation of the application, that the building would be with net zero energy [14]. This status was obtained thanks to the solar collectors and the typological characteristics of the object, with its three sides made of earth, which minimizes its energy needs.

\section{Thermal Efficiency of Underground Housing}

Energy efficiency, with the energy spent on heating and ventilation, as well as other forms of communal requirements in buildings, is often more often studied in above ground structures. The problem is also more prominent for public buildings where the number of residents is often higher than in residential buildings. However, because of the similarity between the problems, it is possible to apply software programs that can be adapted both to aboveground housing, and underground dwellings [15].

\subsection{Aboveground and Earth-Sheltered Building}

The monitoring of the energy characteristics of earth sheltered residential buildings by observing their energy supply needs (heating and cooling) was provided by Staniec and Nowak [16], who compared the basic characteristics of the buildings by comparing the results of aboveground buildings with flat roofs covered by the topsoil layer, and the need for subterranean residential buildings depending on of the characteristics of the soil layers and their thickness. The obtained results indicate the specific benefits of underground residential buildings and that they are specifically dependent on the diffusion of soil layers that serve to build up underground housing.

A connection between typology of residential buildings and energy parameters of structures was observed in relation to two basic types of structures, such as bermed and truly buried underground housing. In this sense, it is possible to categorize them in relation to the four basic divisions as totally 
underground, at zero level, above zero level, and on the hill-side. By comparing the values and impacts according to their typology, Hassan and Sumiyoshi [17] made the conclusion that in the general context preference to thermal stability is given to burial structures that largely depend on the climatic characteristics of the zones in which they were constructed. It is significant that such objects have an insufficient degree of visual acceptability of structures as well as potentials for room lighting.

\subsection{True Underground Buildings}

House in the Town Bu Gheilan/Gharyan/Libya

The main characteristic of the truly underground atrium house is that in most cases they were builtfrom the natural material, such as limestone and clay. Their most advance characteristic is also thatthis type of structure does not pollute the ambient and the landscape.

The main evidence that document the good thermal performance of the underground house in Gharyan, is the facts that in the summer (Figure 1) the indoor temperature is $20^{\circ} \mathrm{C}$ less than the external ambient temperature, and nearly $10{ }^{\circ} \mathrm{C}$ above it in winter (Figure 2).

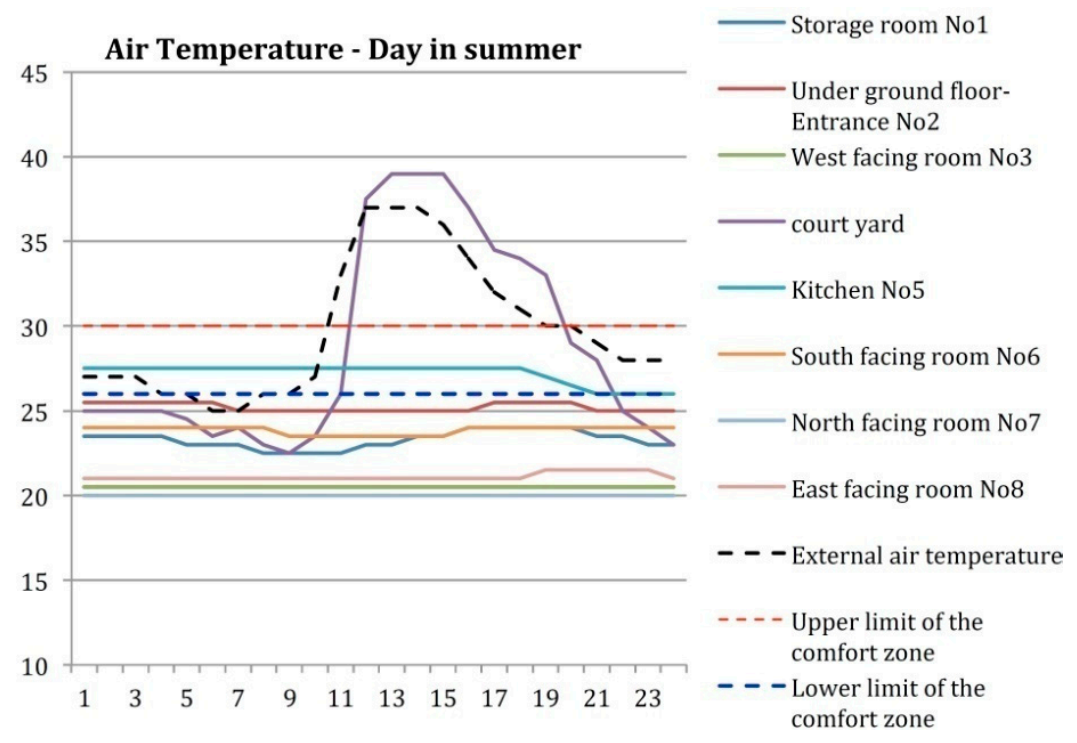

Figure 1. Temperature data: Gharyan during one day in summer [18].

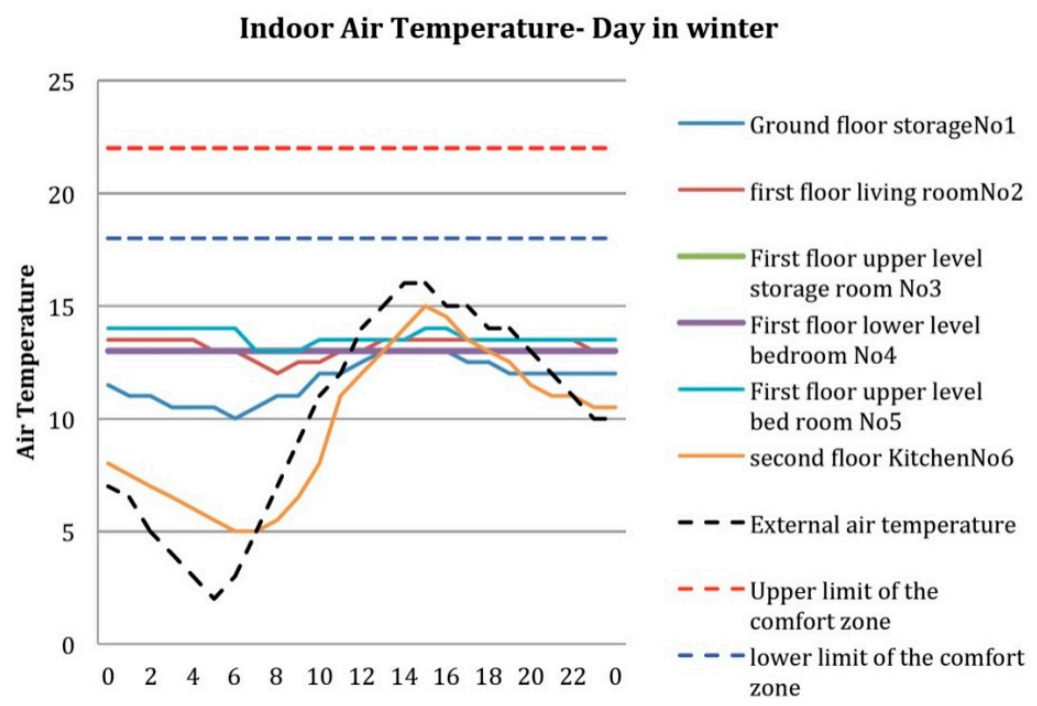

Figure 2. Temperature data: Gharyan during one day in winter [18]. 


\subsection{Bermed}

Old Yaodong House in the Yulin Village/Shaanxi Province/Republic of China

The thermal comfort of old Yaodong cave located at Loess Plateau in Shaaxi Province in Republic of China is unsatisfactory if compared with the modern residences.

In summer, the indoor temperature raises the level of thermal comfort which is sustainable (Figure 3 ) and it is almost $10^{\circ} \mathrm{C}$ less than the external ambient temperature, but in winter it is much below the comfortable situation.

According to the poor condition of old heating system and insulation, in winter days the interior thermal environment is neither good enough for modern standards nor readily controllable. The temperature outside would go down to $-18{ }^{\circ} \mathrm{C}$ in most cases (Figure 4). In order to keep the warmth inside the yaodong cave, it should be completely insulated from the outside conditions [19]. The problem with temperatures below human needs are resolved in modern yaodong homes with new thermally isolated profiles for windows and doors.

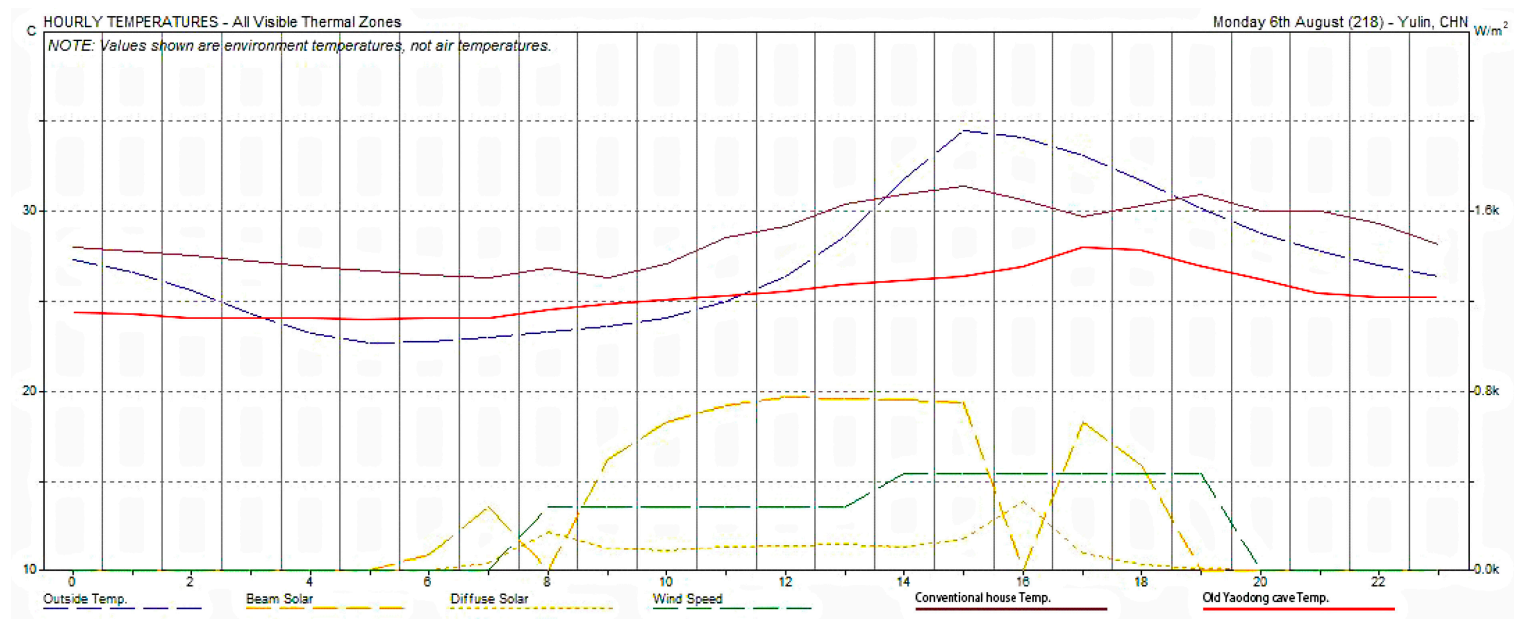

Figure 3. Hourly Temperature in Yulin Village during one day in the summer [19].

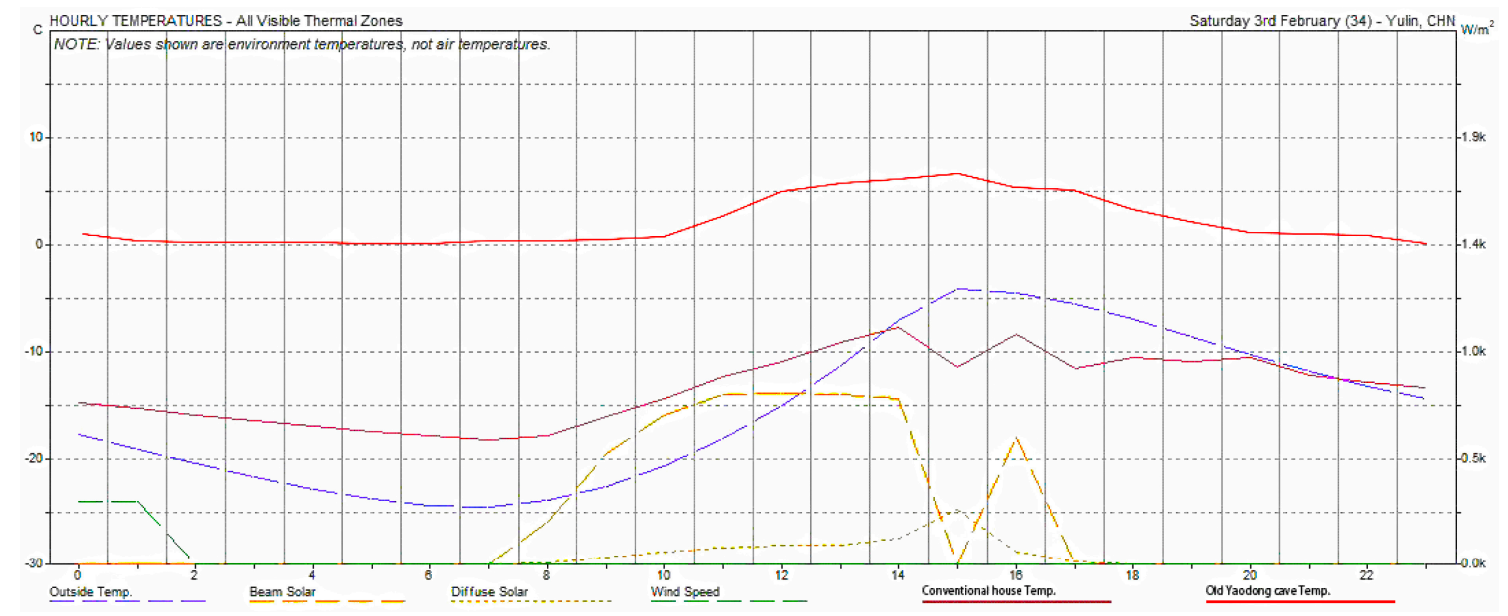

Figure 4. Hourly Temperature in Yulin Village during the one of the coldest day in winter [19].

\section{The Case Study-Dobraca House in Kragujevac, Serbia}

The author's experimental design built in the village Dobraca, near Kragujevac municipality, located in the central part of the Republic of Serbia, will be presented in this section. 


\subsection{Design Process}

The bermed underground earth-sheltered house was designed and inspired by the early Neolithic house (Figure 5a) from the archeological site Lepenski Vir in Serbia. The measurement of the house from Lepenski Vir was the same one that we used for design of the earth sheltered house, in the case of the Dobraca House in Serbia (Figure 5b).

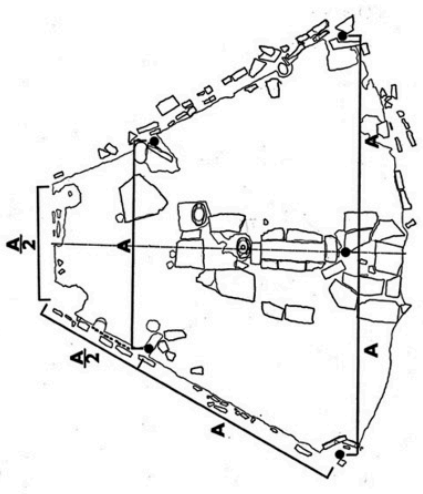

(a)

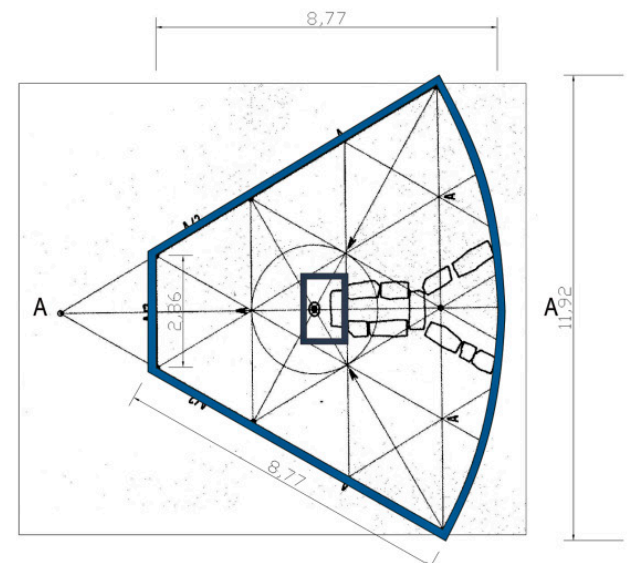

(b)

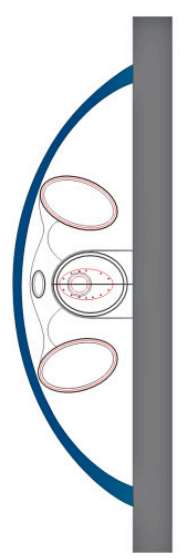

Figure 5. (a) Lepenski Vir: floor plane of the house [20]; (b) floor plane and elevation of Dobraca house (Source: authors).

The terrain was suitable for implementing this kind of structure. The house (Figure 6) was finished in 2008 and the monitoring of average temperature and wind was taken quarterly during the 2012 and 2016.

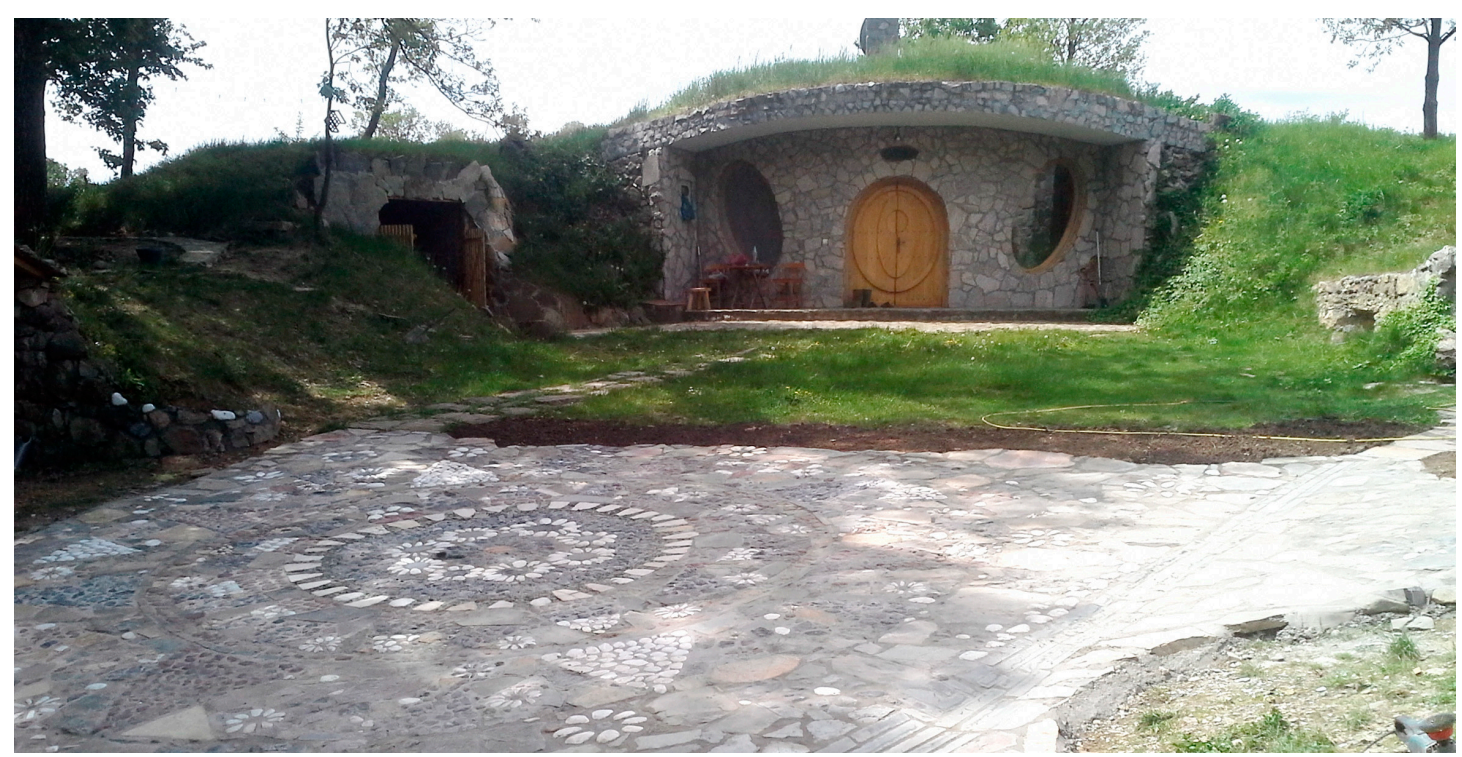

Figure 6. Dobraca bermed earth-sheltered house (Source: authors).

\subsection{Monitoring Some Parameters}

The daily temperature inside and outside the bermed-earth sheltered house in Dobraca was analyzed with special emphasis on the insulation layers and wind speed during 2012 and 2016.

According to the presented measurement (Tables 1 and 2), the temperature inside this bermed-earth sheltered house was in the range from a minimum of $15.8^{\circ} \mathrm{C}$ to maximum $20.6{ }^{\circ} \mathrm{C}$ (even on the coldest winter day in 2012), which is close to the ideal human needs temperature [21]. 
Table 1. Quarterly measured of daily temperature (14 h) during 2012 (Source: authors).

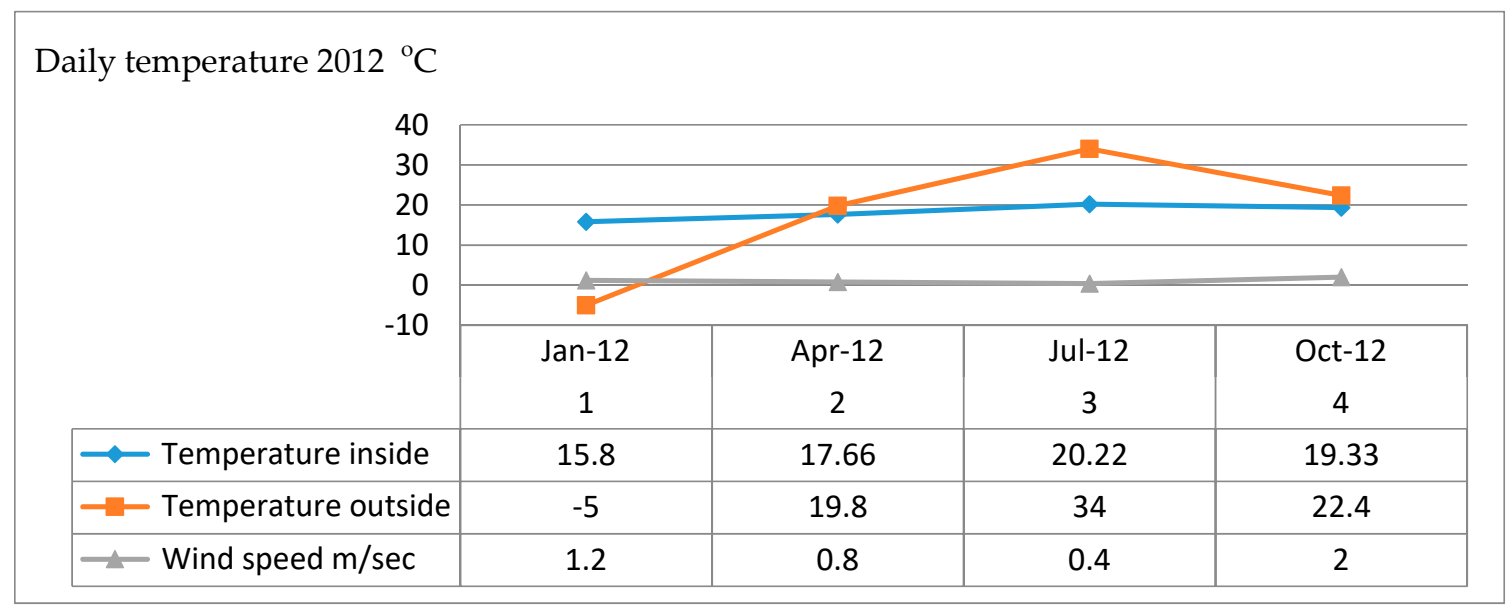

Table 2. Quarterly measured of daily temperature (14 h) during 2016 (Source: authors).

Daily temperature $2016{ }^{\circ} \mathrm{C}$

\begin{tabular}{|c|c|c|c|c|}
\hline $\begin{array}{l}40 \\
35 \\
30\end{array}$ & & & 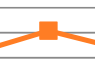 & - \\
\hline 25 & -3 & & & \\
\hline $\begin{array}{l}20 \\
15\end{array}$ & 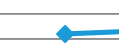 & $\Rightarrow$ & $\longrightarrow$ & \\
\hline $\begin{array}{r}10 \\
5\end{array}$ & r & 4 & 7 & $\Rightarrow$ \\
\hline & lan-12 & Anr-12 & 12 & Oct-12 \\
\hline & 1 & 2 & 3 & 4 \\
\hline$\leadsto$ Temperature inside & 16 & 18 & 20.6 & 19.72 \\
\hline- - Temperature outside & 6 & 20.3 & 35.4 & 22.8 \\
\hline- Wind speed $\mathrm{m} / \mathrm{sec}$ & 2.2 & 2.8 & 3.2 & 3.6 \\
\hline
\end{tabular}

In addition, some authors concluded that underground houses facing eastwards could make a significant heat reduction [22], and we have also noticed that the genuine Lepenski Vir neolithic house on the Danube River has the same orientation as the Dobraca house in Kragujevac. As was expected, the concrete shell structure, with just bituminous coatings and green roof about $0.4 \mathrm{~m}$ thickness provides nearly satisfies the temperature for comfortable living inside the house.

At the Dobraca house location, the wind reaches the operating speed of the small wind turbine as an alternative energy resource. The small wind turbine installed at a height of $10 \mathrm{~m}$ above ground could produce around $2406 \mathrm{kWh}$ of wind energy per year [23]. Since the energy consumption of this small house in Dobraca with about $50 \mathrm{~m}^{2}$ floor space is below $2000 \mathrm{kWh}$, the wind turbine could provide all the necessary electric energy for this house in future. Currently, the Dobraca house uses electrical energy from Kragujevac low-voltage energy network as a part of the Serbian high-voltage electricity transmission system.

According to the data presented in Master plan for mountain Rudnik, the average wind speed in this area is between $2.6-4 \mathrm{~m} / \mathrm{s}$ (Figure 7). 


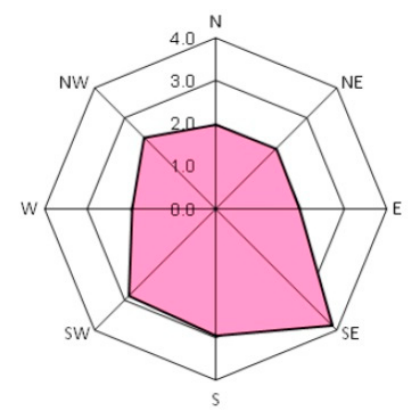

Figure 7. Wind rose graph of wind speed and direction at Rudnik mountain [24].

Average solar irradiation at the Rudnik mountain (Figure 8), based on the data from Master plan Rudnik is relatively high and it is about $1320 \mathrm{kWh}$ [24], which has a great potential for using PV panels as the second alternative energy resource in the case of the Dobraca house (located within an Rudnik mountain influence area). The information presented in this section is basic data that could be used for detailed research of the energy consumption for this house.

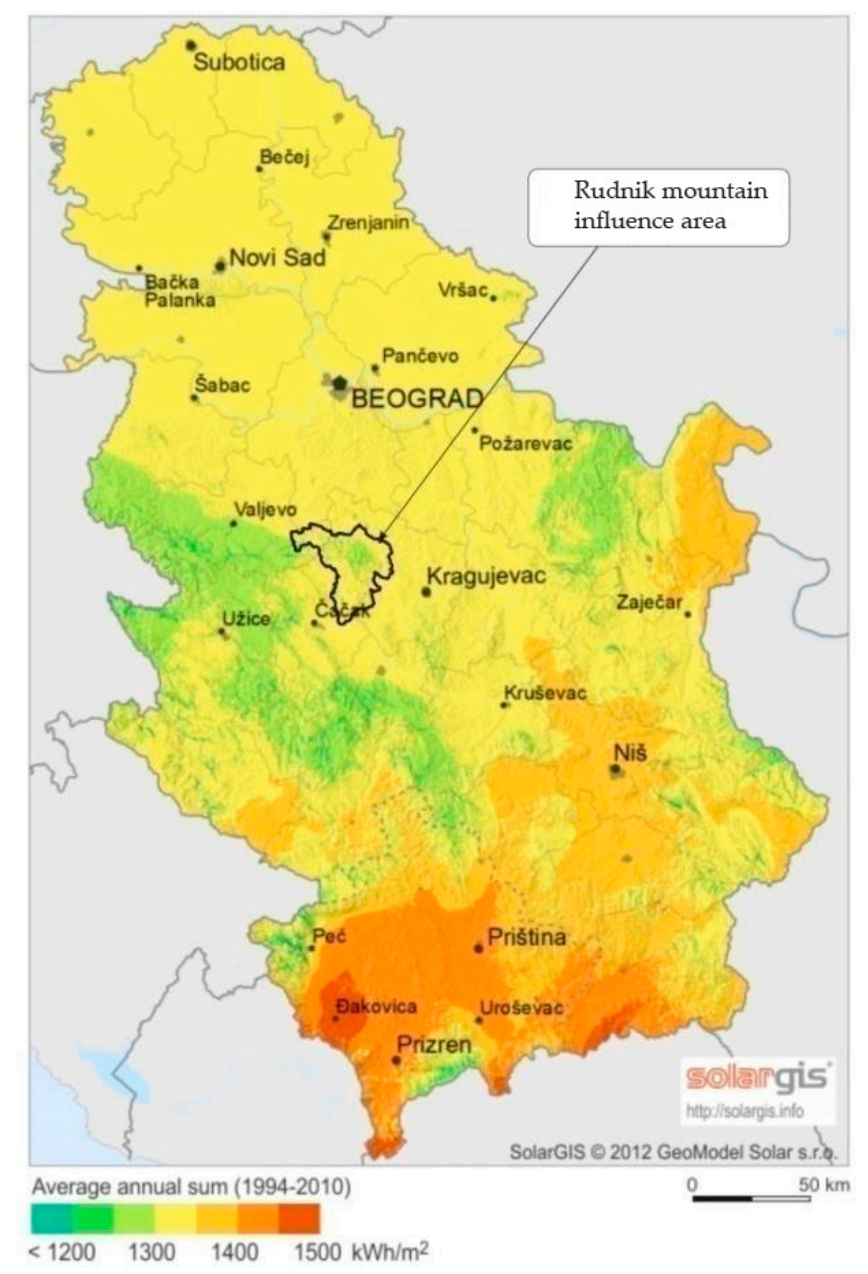

Figure 8. Average solar irradiation at the Rudnik mountain [24].

In the last 30 years, the annual temperature in Kragujevac, has been raised in approximately one degree ${ }^{\circ} \mathrm{C}$ (Figure 9). This temperature is almost equal, with the underground temperature over 10 meters depth (Figure 10). 


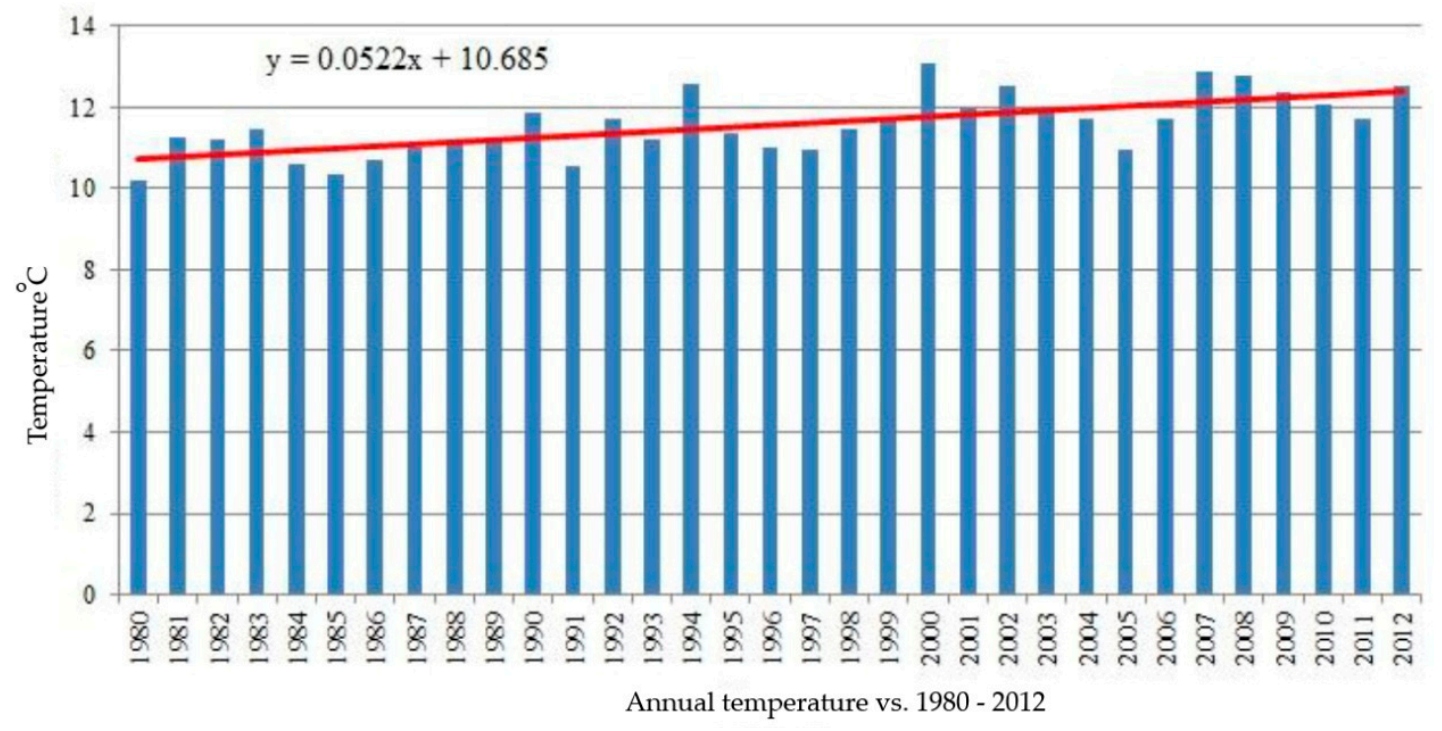

Figure 9. Annual temperature in Kragujevac, Serbia in the period 1980-2012 [24].

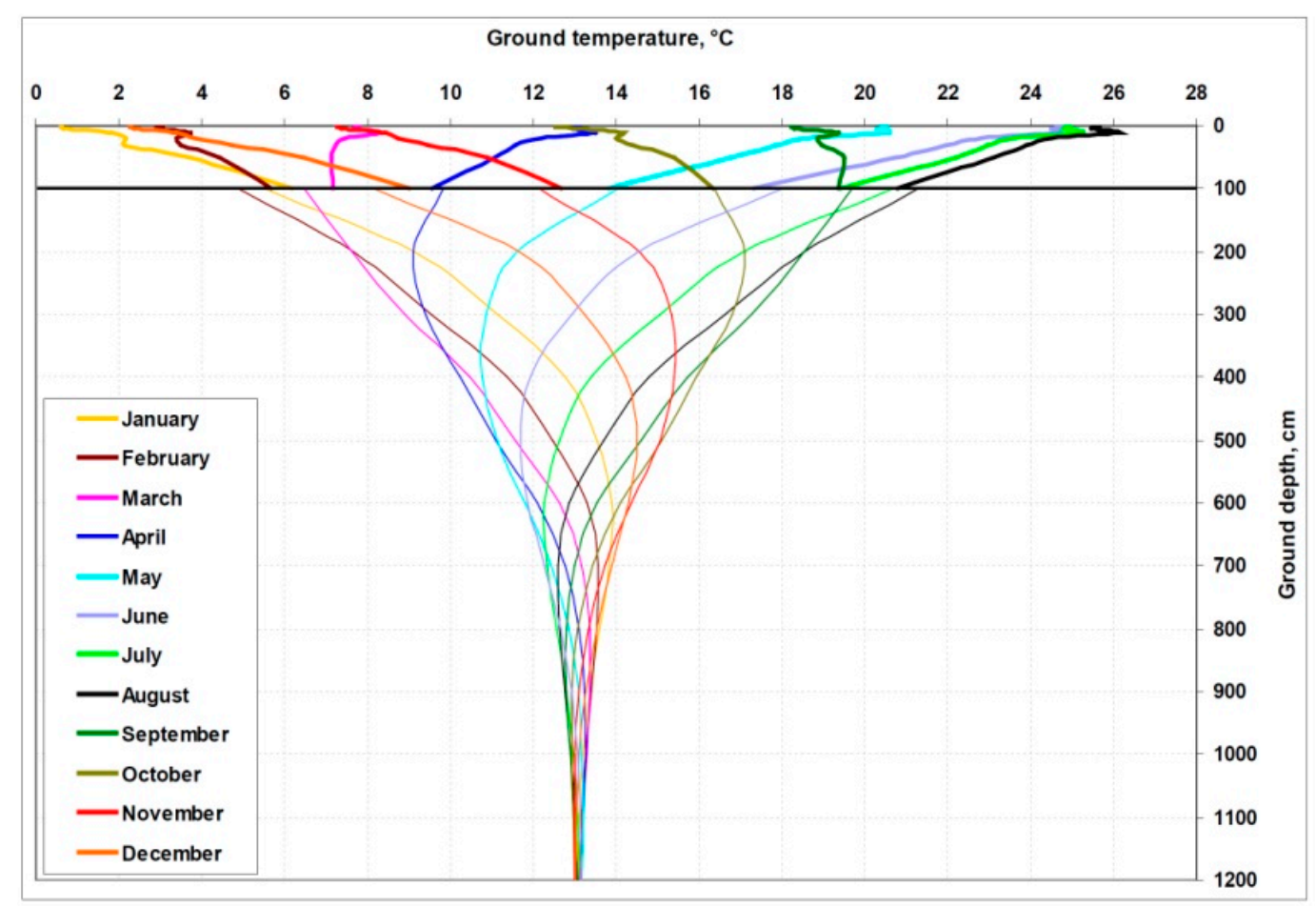

Figure 10. Temperature regarding soil depth in the same climate zone as Case Study house [25].

It can be concluded that while monitoring monthly soil temperature at four $\mathrm{m}$ depth in the temperate zone, it is in the range $12-15{ }^{\circ} \mathrm{C}$, which is close to the average annual temperature in Kragujevac, Serbia.

Figure 11 shows the position of the $75 \mathrm{~m}$ deep well, located $50 \mathrm{~m}$ South-West of the house, with drinking water, but also for non-drinking requirements. 


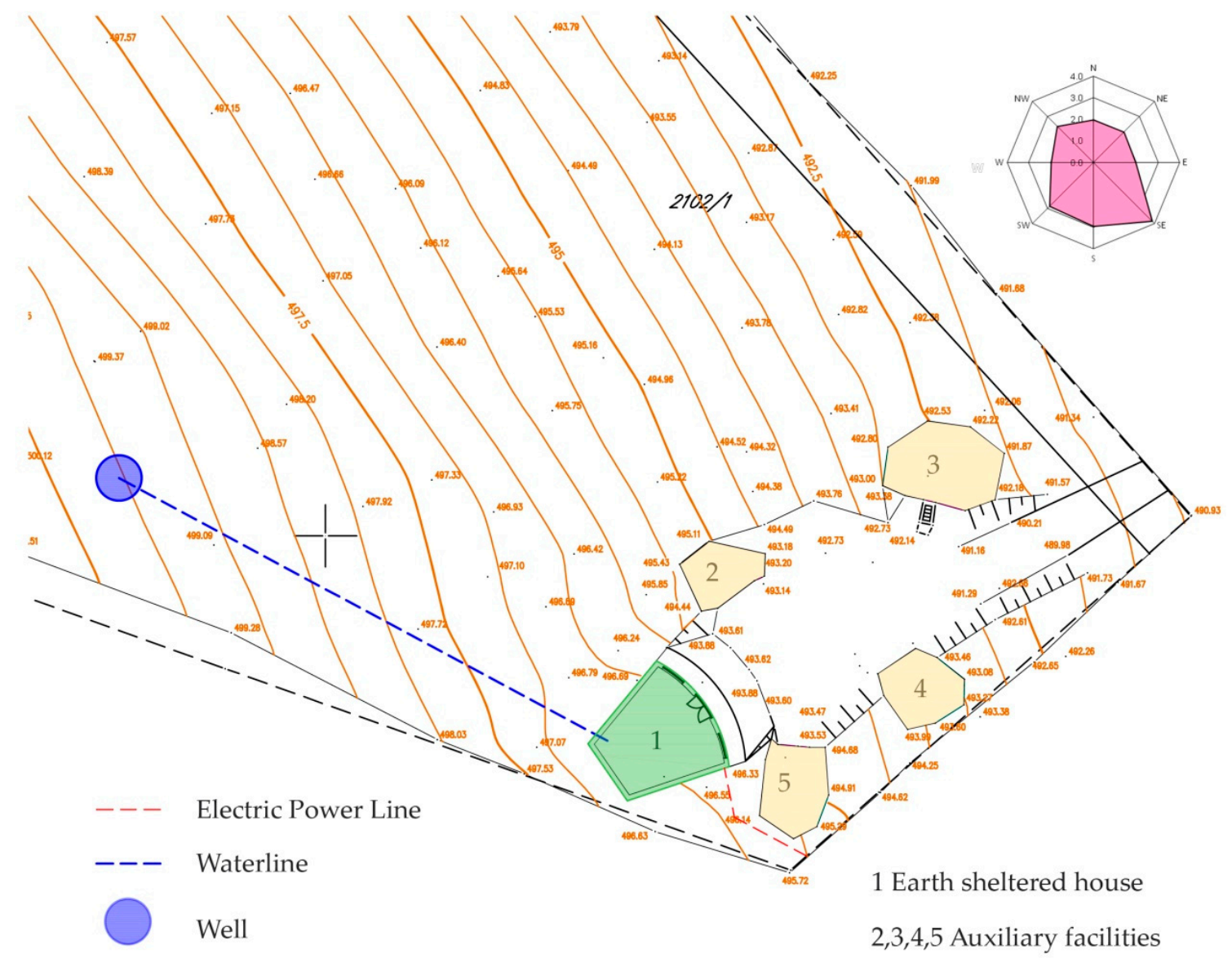

Figure 11. Site plan of the Dobraca house with all the auxiliary facilities (Source: authors).

The water from the well could also be used as separate open loop VSWC systems with water for heating and cooling the house, or as an integrated hybrid system connected with solar PV panels. In future, there is an option for installing the waterproof membrane on the roof for rain harvesting with the possibility to reuse that water for all non-drinking requirements in the house.

The Dobraca house was built at the $12 \%$ terrain slope (Figure 12). That slope provides $3.8 \mathrm{~m}$ of soil above the external walls that are located at the back-side of the building, and $4.05 \mathrm{~m}$ of bermed soil layers on the left and right side of the house.

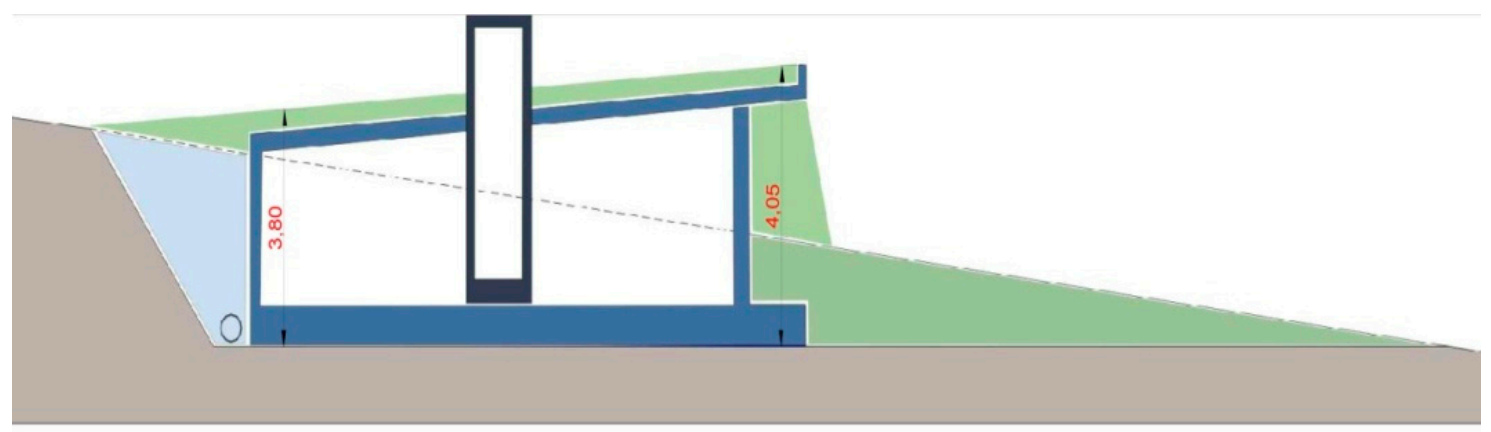

Figure 12. Cross section of Dobraca house with the soil cover measure (Source: authors).

\section{Discussion}

The multifunctionality of underground housing structures is reflected in a number of advantages that these facilities have in relation to aboveground residential buildings. In addition to the landscape protection aspects, the energy aspect in the climate change period becomes the primary aspect related 
to the implementation of exactly this typological form. In addition, it should be noted that these structures are an ideal typological form when it comes to combinations with other energy efficient systems in order to obtain the house that with zero consumption. Energy savings in these forms of construction are mostly reflected in the reduction of energy consumption for the needs of cooling and heating [26]. The earth does not react as fast to temperature changes as the air does. This means that, for instance, if the air surface temperature ranges from $-15{ }^{\circ} \mathrm{C}$ to $35^{\circ} \mathrm{C}$ through the year (winter through summer), then three $\mathrm{m}$ below, the ground's surface temperature will vary only between $10^{\circ} \mathrm{C}$ to $15{ }^{\circ} \mathrm{C}$ [27].

In the search of the ideal typological characteristics of underground residential buildings, Coffee and Crier have designed a courtyard house in Austin, Texas, USA [28]. Their main task was to design thermal efficiency buildings, and the building that could survive the tornado impact. The solar energy panels were also integrated on the site, and it is one of the "pionier" hybrid energy efficiency model of the house, in the late 1970's of the 20th century.

A step further towards the thermal efficiency of underground housing is in the direction of designing a hybrid system by integrating heat pump systems with PV (Figure 13).

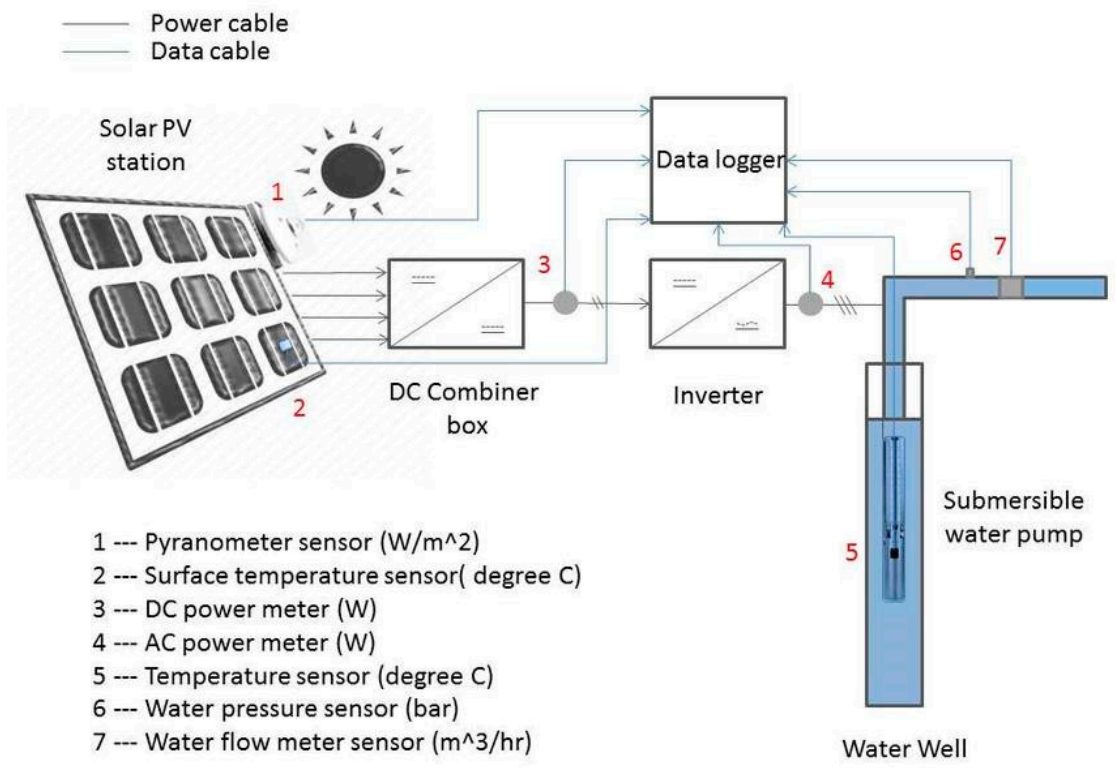

Figure 13. Proposed a full solar water pumping system with monitoring system [29].

Efficiency of energy consumption in above ground and underground structures can be determined by observing the intervals between the established initial and end points of use of energy for heating and cooling. According to Roodman \& Lenssen [30], buildings use 35\% of energy in the world and are directly responsible for $35 \%$ of global emissions. Two-thirds of global electricity production is for building operations. An important consideration for the development, design and construction of buildings with low energy requirements, aside from their usage, are the local, prevailing climate conditions [31].

Climate zones as a belt shaped zones in which the underground structures are located should be considered as a prerequisite for the use of typological models for which the provision of thermal comfort and the achievement of the passive house effects are possible, but with the provision of alternative energy sources such as solar collectors and geothermal pumps.

The achievement of the temperature range of $18-21^{\circ} \mathrm{C}$ in any period of the year represents the ultimate goal of using modern technologies in combination with these typological forms of housing for obtaining a home that is energy efficient but also with ideal thermal comfort and temperature relationships that allow its maximum use. Bermed earth sheltered homes are mostly located at the moderate (temperate) climate zone which enjoys more precipitation with warm not hot weather 
together with mild winter. The earth shelters in this region are located in the North to South direction and the whole part of the Southern façade is covered with large windows for capturing solar energy [32]. True underground house typology could be found mostly in hot and humid climate, where there is an extremely high temperature during the day with the intensive sun radiation.

\section{Conclusions}

The climate changes intensify the energy consumption of household appliances such as heating and cooling equipment, which requires the launch of new and alternative procedures with a large influence on the reduction of the $\mathrm{CO}_{2}$ emissions in the atmosphere. In that sense, the thermal efficiency characteristic of underground buildings could be one of the main reasons for promoting this type of the buildings in future urban planning documentation. Through the historical development and thermal efficiency review in this paper, it has been concluded that the good thermal comfort is one of the important living space characteristic of humans through the history of making the decision to live in the underground structures. While presenting the case study of Dobraca house, the conclusion should be pointed out that in temperate climatic zones, bermed-earth sheltered underground houses are one of the house types for achieving the optimum temperature inside the building with minor inclusion of the alternative energy resources. The result of the Case study earth-sheltered house shows that, with the soil about four $m$ depth, and additional wind energy resources, such as small wind turbines and hybrid PV panels, could bring positive results in order to provide an adequate thermal comfort for inhabitants during the winter.

In this sense, based on the data from this paper, the following conclusions can be drawn:

- The thermal characteristic of the underground housing structures depends on their location and typology and their relations with the climate zone.

- At the temperate climate zone, the entrance facing eastwards is one of the influential factors for keeping the temperature under $21^{\circ} \mathrm{C}$ during the summer time, even if the outside temperature is above $35^{\circ} \mathrm{C}$.

- The green roof with just $0.4 \mathrm{~m}$ of soil, provides enough thickness for keeping the internal temperature stabile.

Taking into account all the mentioned qualities, thermal efficiency is one of the most important ones, and it can be stated that underground earth-sheltered structures, in temperate climate zones with a terrain slope more than $10 \%$, can certainly be recommended as sustainable and desirable habitat models in the 21st century.

Author Contributions: Conceptualization, A.R.M.; Methodology, A.R.M. and N.K.F.; Software, A.R.M.; Validation, N.K.F. and R.F.; Formal Analysis, A.R.M. and N.K.F; Investigation, A.R.M.; Resources, A.R.M. and N.K.F.; Data Curation, N.K.F.; Writing-Original Draft Preparation, A.R.M.; Writing-Review \& Editing, A.R.M. and N.K.F.; Visualization, A.R.M; Supervision, R.F.; Project Administration, A.R.M.

Funding: This research received no external funding.

Acknowledgments: The paper is written as a part of research project TR 36,042 supported by the Ministry of Education, Science and Technological Development of the Republic of Serbia. This support is gratefully acknowledged.

Conflicts of Interest: The authors declare no conflicts of interest.

\section{References}

1. Golany, G. Earth-Sheltered Habitat: History, Architecture, and Urban Design; Van Nostrand Reinhold: New York, NY, USA, 1983; ISBN 978-0442229925.

2. Wines, J. Green Architecture; Taschen: Cologne, Germany; London, UK, 2000; ISBN 3822863033.

3. Efficient Earth-Sheltered Homes. Available online: https://www.energy.gov/energysaver/types-homes/ efficient-earth-sheltered-homes (accessed on 20 February 2018). 
4. Roy, R.L. The Complete Book of Underground Houses, How to Build a Low-Cost Home; Sterling Publishing Company: New York, NY, USA, 1994; ISBN 0-8069-0728-2.

5. Scott, R.G. How to Build Your Own Underground Home; Tab Books: New York, NY, USA, 1985; ISBN 0830697446.

6. Earth Sheltered Design: Guidelines, Examples, and References Paperback; Underground Space Center, Minessota, Van Nostrand Reinhold Company: New York, NY, USA, 1979; ISBN 0442261578.

7. Hall, L. Underground Architecture and Sustainable Design. Available online: http://www. subsurfacebuildings.com/diggingforthegreen.html (accessed on 10 October 2017).

8. Moreland Associates. Earth covered Buildings: An Exploratory Analysis for Hazards and Energy Performance. Available online: https://nehrpsearch.nist.gov/static/files/FEMA/PB82189564.pdf (accessed on 5 February 2018).

9. Eduljee, K.E. Kandovan-Troglodyte Village. Available online: http://www.heritageinstitute.com/ zoroastrianism/kerman/maymand.htm (accessed on 11 June 2015).

10. Matero, F.G. Managing Change: The Role of Documentation and Condition Survey at Mesa Verde National Park. J. Am. Inst. Conserv. 2013, 42, 39-58. [CrossRef]

11. Meir, I.; Gilead, I. Underground Dwellings and Their Microclimate under Arid Conditions. Available online: https:/ / www.researchgate.net/publication/271701045_Underground_dwellings_and_ their_microclimate_under_arid_conditions (accessed on 9 August 2018).

12. The UNESCO Courier, Troglodites the Hiden World. Available online: http://unesdoc.unesco.org/images/ 0010/001020/102011eo.pdf (accessed on 11 September 2018).

13. Dobinson, K.; Bovven, R. Underground Space in the Urban Environment Development and Use; The Warren Centre for Advanced Engineering the University of Sydney: Sydney, Australia, 1997.

14. CPRE Norfolk. Green Buildings in Norfolk. Available online: http://79.170.40.235/cprenorfolk.org.uk/ wp-content/uploads/2012/05/Green-Buildings-in-Norfolk-Booklet-Volume-1.pdf (accessed on 16 August 2018).

15. Harmati, N.; Folić, R.; Magyar, Z.; Dražić, J.; Kurtović Folić, N. Building Envelope Influence on the Annual Energy Performance in Office Buildings. Therm. Sci. Int. Sci. J. 2016, 20, 679-693. [CrossRef]

16. Staniec, M.; Nowak, H. Analysis of the earth-sheltered buildings' heating and cooling energy demand depending on type of soil. Arch. Civ. Mech. Eng. 2011, 11, 221-235. [CrossRef]

17. Hassan, H.; Sumiyoshi, D. Earth-sheltered buildings in hot-arid climates: Design guidelines. Beni-Suef Univ. J. Basic Appl. Sci. 2017. [CrossRef]

18. Gabril, N.M.S. Thermal Comfort and Building Design Strategies for Low Energy Houses in Libya, Lessons from the Vernacular Architecture. University of Westminster FOR the Degree of Doctor of Philosophy; 2014. Available online: https://westminsterresearch.westminster.ac.uk/download/ e399dcce1c103edd983ec0b383ef047146154d2611faa725ae079311c7f02279/66293851/Nadya\%20Gabril\% 20PhD\%20thesis.pdf (accessed on 11 February 2018).

19. Yonghe, C. The Renovation of Traditional Cave Housing in China, Tesi Specialistiche/Magistrali, Architettura-MI, Politecnico di Milano, I Facolta di Architettura MI, A.A. 2010-2012. Available online: https: / / www.politesi.polimi.it/handle/10589/80374?mode=full\&submit_simple=Visualizza+tutti+ i+metadati+del+documento (accessed on 11 February 2018).

20. Srejović, D. Lepenski Vir.; OCLC18569256; Srpska Književna Zadruga: Beograd, Srbija, 1969.

21. Wookey, R.; Bone, A.; Carmichael, C.; Crossley, A. Minimum Home Temperature Thresholds for Health in Winter-A systematic Literature Review. Available online: https://assets.publishing.service.gov.uk/ government/uploads/system/uploads/attachment_data/file/468196/Min_temp_threshold_for_homes_ in_winter.pdf (accessed on 17 July 2018).

22. Nenad, B. Miloradovic, Lepenski Vir-The Prehistoric Energy Efficient Architecture. Available online: https:/ / www.rehva.eu/fileadmin/REHVA_Journal/REHVA_Journal_2016/RJ_issue_5/p.54/5459_RJ1605_WEB.pdf (accessed on 22 July 2018).

23. Wind Energy Potential of Gaza Using Small Wind Turbines: A Feasibility Study. Available online: http: / / www.mdpi.com/1996-1073/10/8/1229/pdf (accessed on 21 August 2018).

24. University of Kragujevac, Master Plan for the Sustainable Development of Rudnik Mountain. Available online: http:/ /www.kg.ac.rs/Docs/MPPR_10_06_2014_konacno.pdf (accessed on 12 July 2018). 
25. Kurevija, T.; Vulin, D.; Krapec, V. Influence of Undisturbed Ground Temperature and Geothermal Gradient on the Sizing of Borehole Heat Exchangers. Available online: http:/ / www.ep.liu.se/ecp/057/vol5/017/ ecp57vol5_017.pdf (accessed on 19 August 2018).

26. Van Dronkelaar, C.; Costola, D.; Mangkuto, R.A.; Hensen, J.L.M. Heating and Cooling Energy Demand in Underground Buildings: Potential for Saving in Various Climates and Functions. Available online: https: / / pure.tue.nl/ws / files/46939322/759645-1.pdf (accessed on 7 July 2018).

27. Al-Mumin, A.A. Suitability of sunken courtyards in the desert climate of Kuwait. Energy Build. 2001, $103-111$. [CrossRef]

28. Labs, K. The Architectural Underground, Underground Space. Available online: http://media.journals. elsevier.com/content/files/the-architectural-underground-part-11063614.pdf (accessed on 10 February 2018).

29. Elrefai, M.; Hamdy, R.A.; ElZawawi, A.; Hamad, M.S. Design and Performance Evaluation of a Solar Water Pumping System: A Case Study. 2016. Available online: https://www.researchgate.net/publication/ 313452521_Design_and_performance_evaluation_of_a_solar_water_pumping_system_A_case_study (accessed on 26 August 2018).

30. Roodman, D.M.; Lenssen, N.K.; Peterson, J.A. A Building Revolution: How Ecology and Health Concerns Are Transforming Construction; World Watch Institute: Washington, DC, USA, 1995; ISBN 1878071254.

31. Bauer, M.; Mösle, P.; Schwarz, M. Green Building: Guidebook for Sustainable Architecture; Springer: Berlin, Germany, 2009. Available online: http://library.uniteddiversity.coop/Ecological_Building/Green_BuildingGuidebook_for_Sustainable_Architecture.pdf (accessed on 12 August 2018).

32. Mirrezaei, S.A. An Ecological Study on Earth Sheltered Housing in Different Climates. Master of Science in Architecture, Eastern Mediterranean University, Gazimağusa, North Cypress. 2015. Available online: http:// i-rep.emu.edu.tr:8080/xmlui/bitstream/handle/11129/2954/mirrezaeiseyedeh.pdf?sequence=1 (accessed on 24 February 2018).

(C) 2018 by the authors. Licensee MDPI, Basel, Switzerland. This article is an open access article distributed under the terms and conditions of the Creative Commons Attribution (CC BY) license (http:/ / creativecommons.org/licenses/by/4.0/). 